Research Article

\title{
Sequence and expression pattern of the germ line marker vasa in honey bees and stingless bees
}

\author{
Érica Donato Tanaka ${ }^{1,2}$ and Klaus Hartfelder ${ }^{3}$ \\ ${ }^{1}$ Departamento de Biologia, Faculdade de Filosofia, Ciências e Letras de Ribeirão Preto, \\ Universidade de São Paulo, Ribeirão Preto, SP, Brazil. \\ ${ }^{2}$ Institut de Biologia Evolutiva, Consejo Superior de Investigaciones Cientificas, \\ Universitat Pompeu Fabra, Barcelona, Spain. \\ ${ }^{3}$ Departamento de Biologia Celular e Molecular e Bioagentes Patogênicos, \\ Faculdade de Medicina de Ribeirão Preto, Universidade de São Paulo, Ribeirão Preto, SP, Brazil.
}

\begin{abstract}
Queens and workers of social insects differ in the rates of egg laying. Using genomic information we determined the sequence of vasa, a highly conserved gene specific to the germ line of metazoans, for the honey bee and four stingless bees. The vasa sequence of social bees differed from that of other insects in two motifs. By RT-PCR we confirmed the germ line specificity of Amvasa expression in honey bees. In situ hybridization on ovarioles showed that Amvasa is expressed throughout the germarium, except for the transition zone beneath the terminal filament. $\mathrm{A}$ diffuse vasa signal was also seen in terminal filaments suggesting the presence of germ line cells. Oocytes showed elevated levels of Amvasa transcripts in the lower germarium and after follicles became segregated. In previtellogenic follicles, Amvasa transcription was detected in the trophocytes, which appear to supply its mRNA to the growing oocyte. A similar picture was obtained for ovarioles of the stingless bee Melipona quadrifasciata, except that Amvasa expression was higher in the oocytes of previtellogenic follicles. The social bees differ in this respect from Drosophila, the model system for insect oogenesis, suggesting that changes in the sequence and expression pattern of vasa may have occurred during social evolution.
\end{abstract}

Key words: Apis mellifera, Melipona quadrifasciata, vasa, social insect, oogenesis.

Received: January 27, 2009; Accepted: April 24, 2009.

\section{Introduction}

The decision of who is to reproduce and who is not is a key question in the evolution of sociality. In the highly eusocial Hymenoptera, this decision has become fixed into a system of reproductive division of labor between two morphologically distinct female phenotypes, the queen and worker. Honey bees (Apini) and stingless bees (Meliponini) belong to the subfamily Apinae (Michener, 2000). Both are highly eusocial, but they differ considerably in their life history characteristics (Sakagami, 1982; Imperatriz-Fonseca and Kleinert, 1998). Besides exhibiting a much more flexible age polyethism (Waldschmidt and Campos, 1997) than Apis mellifera, a major difference between stingless bees and honey bees concerns ovary development and worker reproduction (Hartfelder et al., 2006).

When a honey bee queen emerges from the brood cell, each of her two ovaries consists of 180-200 ovarioles.

Send correspondence to Érica Donato Tanaka. Institut de Biologia Evolutiva, Consejo Superior de Investigaciones Científicas, Universitat Pompeu Fabra, Passeig Marítim de la Barceloneta 37-49, E-08003 Barcelona, Spain. E-mail: erica.donato@ibe.upf-csic.es.
These are activated soon after mating, allowing her to lay up to 2,000 eggs per day. In contrast, adult workers have only 2-10 ovarioles in each ovary (Snodgrass, 1956). In the presence of the queen, only very few workers show signs of progressive oogenesis (Visscher and Dukas, 1995), an exception being a mutant phenotype, the so-called anarchistic workers (Barron and Oldroyd, 2001).

Queens and workers of stingless bees do not exhibit such drastic differences in ovariole number and, in terms of gonad size, the two castes differ primarily in the length of the ovariole filaments (Hartfelder and Engels, 1992; Cruz-Lan$\operatorname{dim}$ et al., 1998). Interestingly, worker reproduction in stingless bees covers the entire spectrum, from full fertility in the presence of the queen (Imperatriz-Fonseca and Kleinert, 1998) to complete sterility due to ovary degeneration during metamorphosis (Boleli et al., 1999). This marked variation in ovary structure and reproductive biology makes social bees an interesting group for comparative studies on oogenesis.

Recent studies on oogenesis progress and control in Apis mellifera have raised several questions concerning the presence of putative germ-line stem cells in the terminal fil- 
ament (Gutzeit et al., 1993; Tanaka and Hartfelder, 2004), on programmed cell death during oogenesis (Tanaka et al., 2006), and on the control of vitellogenesis via expression of the vitellogenin receptor encoding gene (Guidugli-Lazzarini et al., 2008). These studies generally compared honey bee oogenesis with corresponding processes in the fruit fly, Drosophila melanogaster, which also has a polytrophic meroistic type of ovary and for which the genetics of germ cell determination and differentiation are much better understood (for reviews see, King, 1970; de Cuevas et al., 1997; Gilboa and Lehmann, 2004).

Of specific interest to the determination of the germ line is the vasa gene product. Vasa protein, an ATPdependent DEAD-box RNA helicase (Hay et al., 1988; Pyle, 2008), is a conserved germ line-specific marker for most metazoan phyla (Fujiwara et al., 1994; Gruidl et al., 1996; Olsen et al., 1997; Shibata et al., 1999; Mochizuki et al., 2001; Extavour and Akam, 2003; Sagawa et al., 2005; Rebscher et al., 2007). In Drosophila oogenesis, Vasa protein surrounds germ cell nuclei in the germarium and in early egg chambers. Later on (stage 10), vasa mRNA appears at first homogeneously distributed throughout the oocyte cytoplasm before the protein becomes asymmetrically segregated to the posterior pole (Hay et al., 1988; Liang et al., 1994; Sano et al., 2002; Findley et al., 2003). In the grasshopper Schistocerca gregaria, which has a panoistic type ovary, vasa mRNA, as well as Vasa protein are highly expressed in the early stages of oogenesis, with levels rapidly falling in maturing oocytes (Chang et al., 2002).

Due to the highly conserved association of vasa expression with germ line development and gametogenesis in metazoans (Extavour, 2007), efforts were made to identify a bona fide vasa ortholog in the sequenced honey bee genome (Dearden et al., 2006; The Honey Bee Genome Sequencing Consortium, 2006). Since this computationally predicted vasa sequence revealed a divergence in one of the characteristic Vasa motifs, being a change from ARKF to IVKF (Dearden et al., 2006), the question became whether this change may be specific to the honey bee, as part of its special social biology, or whether it may have preceded social evolution in the corbiculate bees. Furthermore, we were interested to see whether vasa gene function, and especially its localization in the germ cells may differ between honey bees and stingless bees, as part of their divergence in worker reproduction. In the present study we sequenced vasa orthologs for four species of stingless bees and, by RT-PCR and in situ hybridization with a honey bee vasa probe, we compared vasa expression patterns in Apis mellifera ovaries with those of the stingless bee Melipona quadrifasciata.

\section{Materials and Methods}

\section{Bees}

Apis mellifera queens and workers were obtained from Africanized honey bee stocks. Worker larvae and pu- pae were collected directly from brood frames and staged (Michelette and Soares, 1993). Queens were reared following standard apicultural procedures. Pharate adult queens and workers were allowed to hatch in an incubator $\left(34^{\circ} \mathrm{C}\right.$, $80 \%$ r.h.). Newly emerged workers were paint-marked and reintroduced into queenless hives, from where they were retrieved two weeks later when their ovaries were expected to be active (Makert et al., 2006). Queens that were to be aged without mating (virgin queens) were caged individually in plastic queen cages and were kept in hives until they reached the appropriate age. Other queens were paintmarked after hatching and were shortly thereafter introduced into queenless hives where they were allowed to mate naturally. Once they started to lay eggs they were retrieved for ovary analysis.

Melipona quadrifasciata queens and workers were collected from laboratory colonies. To obtain virgin queens of known age, combs with pharate-adult brood were removed and transferred to an incubator $\left(28^{\circ} \mathrm{C}, 80 \%\right.$ r.h. $)$ for up to $16 \mathrm{~h}$. Newly emerged queens were kept in Petri dishes, each accompanied by five workers, and were maintained in the incubator until they reached the adequate age for analysis. These bees received sugar water, fermented pollen paste and water ad libitum. Specimens of the other three stingless bee species, Melipona scutellaris, Scaptotrigona postica [frequently also referred to as Scaptotrigona aff. depilis, due to uncertainties in the taxonomy of this genus, (Camargo and Pedro, 2007)] and Frieseomelitta varia were also collected from brood frames of laboratory colonies, as described for M. quadrifasciata.

\section{Sequencing and bioinformatics analysis}

For experimental confirmation of the computationally predicted honey bee vasa ortholog (GB14804-PA) (Dearden, 2006; The Honey Bee Genome Sequencing Consortium, 2006) we designed gene-specific primers aligning to five regions in the predicted coding sequence (V7F0: 5'-ATGGCTGATGACTGGGGT-3'; V7R1: 5'-CCATA ACTACGTCCACCTTC-3'; V7F2: 5'-GAGGAAAGTT GTCTGCTGG-3'; V7R2: 5'-CCAGCAGACAACTTTC CTC-3'; V7F3: 5'-GCCGTTTTCTTATCCGAG-3'; V7R3: 5'-CTCGGATAAGAAAACGGC-3'; V7R4: 5'CCGGTTCTT TGCTACG-3') and one in the predicted 3'UTR region (V7R5: 5'-GAAACAAAGCTTACTACC CTG-3'). RT-PCR conditions were as follows: $95^{\circ} \mathrm{C}$ for 5 min, followed by 35 cycles of $94{ }^{\circ} \mathrm{C}$ for $30 \mathrm{~s}, 50{ }^{\circ} \mathrm{C}$ for $30 \mathrm{~s}, 72{ }^{\circ} \mathrm{C}$ for $30 \mathrm{~s}$, and a final extension step at $72{ }^{\circ} \mathrm{C}$ for $7 \mathrm{~min}$. The amplification products of expected size (V7F0+V7R1: 100 bp, V7F0+V7R2: 900 bp, V7F2+V7R3: 500 bp, V7F2+V7R4: 900 bp, V7F3+V7R4: $500 \mathrm{bp}, \mathrm{V7F} 3+\mathrm{V} 7 \mathrm{R} 5: 700 \mathrm{bp}$ ) were ligated into pGEM-T Easy vector (Promega) for transformation of competent DH5 $\alpha$ E. coli cells.

To identify vasa orthologs in the four stingless bee species, Melipona quadrifasciata, Melipona scutellaris, 
Frieseomelitta varia and Scaptotrigona postica, we used primer combinations originally designed to amplify Apis mellifera vasa (V7F0+V7R2, V7F2+V7R3, V7F3+V7R4). DNA sequencing was performed by the dideoxy sequencing method, using a BigDye terminator v3.0 Cycle Sequencing Ready Reaction (Applied Biosystems) in an ABI Prism 310 Genetic Analyzer (Applied Biosystems).

For annotation of the honey bee vasa gene, the CDS assembled from the RT-PCR products was aligned against the genome sequence (Amel. 4.0, The Honey Bee Genome Sequencing Consortium, 2006) using a LINUX-based Artemis platform (version 7.1, The Sanger Institute). Sequence homology searches were performed by BLAST (blastx algorithm) to retrieve putative vasa orthologs of two other hymenopteran species, Copidosoma floridanum (GenBank accession number AAT11555.1) and Nasonia vitripennis (GenBank accession number XM_001603906.1). The vasa orthologs of these two species and those of the honey bee and the four stingless bee species obtained in this study were used in ClustalW multiple alignments, with $D$. melanogaster vasa as an outgroup. The ClustalW results were transformed to Mega 3.1 format (Kumar et al., 2004). The Neighbor joining procedure (Saitou and Nei, 1987) was used for tree construction, which was evaluated by 1000 bootstrap repetitions.

\section{RT-PCR analysis of vasa expression in Apis mellifera ovaries}

RNA was extracted using TRIzol reagent (Invitrogen) from pools of 15-20 ovary pairs each. First-strand cDNA was synthesized using an oligo $(\mathrm{dT})_{12-18}$ primer (Invitrogen) and Superscript II (Invitrogen) reverse transcriptase. RT-PCR reactions were carried out using the Amvasa primers V7F2 and V7R 3 at $94{ }^{\circ} \mathrm{C}$ for 2 min followed by 32 cycles of $94{ }^{\circ} \mathrm{C}$ for $30 \mathrm{~s}, 55^{\circ} \mathrm{C}$ for $30 \mathrm{~s}, 72^{\circ} \mathrm{C}$ for $30 \mathrm{~s}$, and a final extension step at $72{ }^{\circ} \mathrm{C}$ for $7 \mathrm{~min}$. For normalization we amplified a cytoplasmatic actin gene fragment (GenBank accession number AB023025), an endogenous control gene appropriate for quantitative gene expression analysis in honey bees (Lourenço et al., 2008). The number of amplification cycles was adjusted to avoid saturation. The Amvasa amplification products were analyzed by electrophoresis in $1 \%$ agarose gels containing ethidium bromide.

For the analysis of vasa expression in honey bee tissues other than the ovaries we prepared first-strand cDNA from brain, fat body, midgut, thorax (dorsal tegument) and abdomen (dorsal tegument) from newly emerged queens and workers. Additional samples were prepared from spermathecae of queens and from hypopharyngeal glands of workers, both of which are organs of caste-specific functions.

\section{In situ hybridization}

For in situ localization of vasa transcripts in honey bee and stingless bee ovaries, sense and antisense probes were synthesized using Amvasa-specific primers containing a $\mathrm{T} 7$ promoter sequence (underlined) at the respective 5'-ends (ISH-F1: 5'-TAATACGACTCACTATAGGGCG AGGTAGAGGTCATGGTAAAGGAG-3' and ISH-R1: 5'-TAATACGACTCACTATAGGGCGAGAGGCACAT TATCTCCACTCAC-3'), in combination with corresponding primers lacking the T7 sequence (ISH-F2 and ISH-R2). Amplification parameters were: $94{ }^{\circ} \mathrm{C}$ for $2 \mathrm{~min}$, followed by 40 cycles of $94{ }^{\circ} \mathrm{C}$ for $40 \mathrm{~s}, 57^{\circ} \mathrm{C}$ for $40 \mathrm{~s}$, $72{ }^{\circ} \mathrm{C}$ for $40 \mathrm{~s}$, and a final extension step at $72{ }^{\circ} \mathrm{C}$ for $7 \mathrm{~min}$. PCR reactions with these primers generated a product of $331 \mathrm{bp}$. The antisense and sense products were produced by the primer combinations ISH-F2 + ISH-R1 and ISH-F1+ ISH-R2, respectively.

Aliquots of the amplification products were checked on agarose gels, purified (Wizard ${ }^{\circledR}$ SV Gel and PCR Clean-Up System, Promega) and quantified spectrophotometrically. RNA probes were generated by in vitro transcription from the $\mathrm{T} 7$ promoter using the DIG RNA Labelling Kit (SP6/T7) (Roche Applied Science). The transcription products were precipitated by addition of $1 \mu \mathrm{L}$ ammonium acetate $(10 \mathrm{M})$ and $20 \mu \mathrm{L}$ isopropanol. After centrifugation, the pellet was washed in $70 \%$ ethanol. The ethanol-free probes were resuspended in $50 \mu \mathrm{L}$ hybridization buffer $(50 \%$ formamide, 4 X SSC, 1 X Denhardt's solution, $250 \mu \mathrm{g} / \mathrm{mL}$ yeast extract, $250 \mu \mathrm{g} / \mathrm{mL}$ salmon sperm DNA, $50 \mu \mathrm{g} / \mathrm{mL}$ de heparin, $0,1 \%$ Tween- $20,5 \%$ dextrane sulfate) before storage at $-20{ }^{\circ} \mathrm{C}$.

Ovariole whole mounts were prepared for $A$. mellifera workers kept in queenright and queenless conditions, for mated and unmated queens, as well as for physogastric and virgin queens of M. quadrifasciata. After dissection of the ovaries, the ovarioles were separated in honey bee tissue culture medium (Rachinsky and Hartfelder, 1998) and the ovariole sheath was removed from each ovariole by means of watchmaker's forceps (number 5 , Dumont). Fixation of the ovarioles and the subsequent hybridization and detection reactions were performed following the protocol optimized by Osborne and Dearden (2005) for in situ hybridization studies on honey bees.

\section{Results}

\section{Sequence characteristics of Apis mellifera and Melipona quadrifasciata vasa genes}

The Apis mellifera vasa gene spans an Open Reading Frame (ORF) of 1,893 bp, divided into 3 exons that are separated by 2 small introns (Figure 1A). The product sequenced in our study from overlapping RT-PCR fragments aligned $100 \%$ with the computationally predicted Apis mellifera vasa gene sequence (GenBank accession number 
$\mathrm{ABC}$ 41341). Conceptual translation resulted in a predicted protein of 630 amino acids (AmVasa). Sequence similarity scores obtained by BLASTP analysis showed that AmVasa was 55 to $61 \%$ identical to the Vasa proteins of members of other insect orders, including the orthopterans Schistocerca gregaria and Gryllus bimaculatus, the lepidopteran Bombyx mori, the coleopteran Tribolium castaneum, and the dipterans Aedes aegypti, Anopheles gambiae, Culex pipiens quinquefasciatus and Drosophila melanogaster (Supplementary Material, Figure S1).

Apis mellifera Vasa contains all the nine conserved domains characteristic for the DEAD-box helicase family (GxxxPxxIQ, AxTGxGKT, PTRELA, TPGR, DEAD, SAT, GG, ARGLD, HRIGRTGR) and two of the conserved domains of the Vasa subfamily (GIVGxA, ExEExW) (Supplementary Material, Figure S1). AmVasa, however, differs in two potentially important aspects from the Vasa proteins of other insect species. First, the Vasaspecific ARKF domain presented a change in the first two amino acids, being IVKF in AmVasa. Second, the arginine-glycine-glycine (RGG) repeat, which is frequently found in N-terminal regions of many Vasa-related proteins, was represented in AmVasa by a single RGG copy only. The computationally predicted CDS encoding AmVasa (Dearden, 2006) was, thus, fully confirmed by assembly of RT-PCR fragments, including the modifications in the two above mentioned motifs.
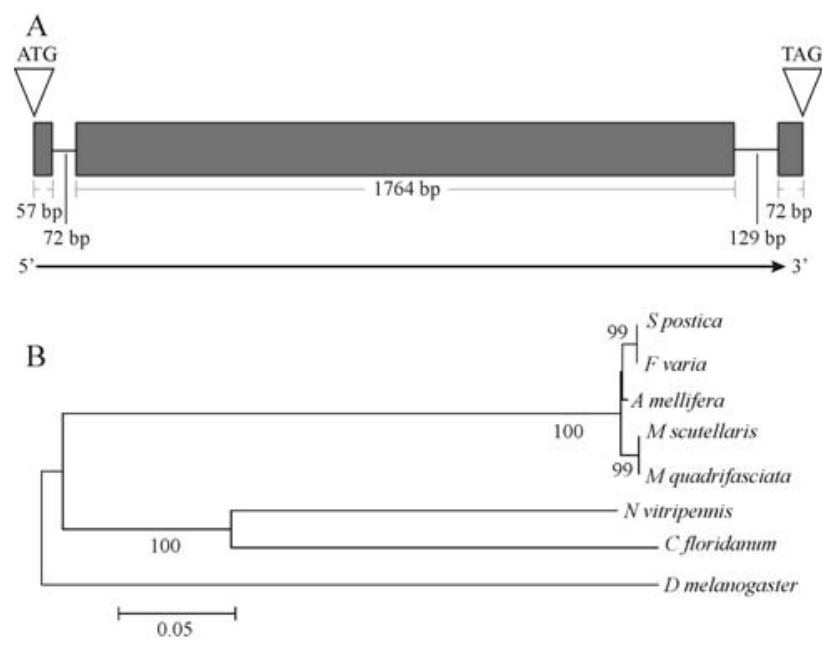

Figure 1 - The vasa genes of highly eusocial bees. (A) Schematic diagram of the genomic region encoding the vasa gene of the honey bee Apis mellifera. The open arrowheads on the left and right indicate the start and stop codons, respectively. Exons are represented as boxes and their respective sizes are shown. Intron length was scaled to provide a general estimate of vasa gene size. (B) Molecular phylogeny for hymenopteran Vasa protein sequences. Vasa proteins of two species of parasitic wasps, Nasonia vitripennis and Copidosoma floridanum were aligned with Vasa protein sequences of the stingless bees Melipona scutellaris, Melipona quadrifasciata, Scaptotrigona postica and Frieseomelitta varia, as well as with Apis mellifera Vasa protein. Drosophila melanogaster Vasa was included as outgroup. ClustalW alignment results (Supplementary Material Figure S2) were used as input for tree construction by Neighbor joining (NJ). Results of 1,000 bootstrap repetitions are shown adjacent to the respective branches.
For the stingless bee, Melipona quadrifasciata, conceptual translation of the vasa ortholog (partial cds, GenBank accession number FJ161962) resulted in a predicted protein (MqVasa) of 624 amino acid residues showing $98 \%$ sequence identity to Apis mellifera Vasa protein. A similarly high degree of identity as that between the vasa genes of A. mellifera and M. quadrifasciata was also obtained for the vasa orthologs of the three other stingless bee species, Melipona scutellaris (GenBank accession number EF601038), Scaptotrigona postica (GenBank accession number EF601037) and Frieseomelitta varia (GenBank accession number FJ161963). In the molecular phylogeny tree constructed by Neighbor Joining (Figure 1B) the Vasa sequences of the five bee species came out as a well supported branch, separated from the parasitic wasps Nasonia vitripennis and Copidosoma floridanum, both belonging to Chalcidoidea. Interestingly, the two Melipona species were also well separated from the two trigonine species $S$. postica and $F$. varia.

In the ClustalW alignments of the hymenopteran Vasa proteins, with Drosophila as outgroup (Supplementary Material - Figure S2), the following observations concerning modifications in characteristic Vasa motifs are noteworthy: (1) in the GxxxPxxIQ domain the five bee species are all GYKKPTPVQK, differing from Nasonia and Copidosoma in the third and fourth position, (2) in the PTRELA domain, Copidosoma is identical to Drosophila, differing from Nasonia and the bees, which are all PTRELT, (3) in the GIVGxA domain, Nasonia and Copidosoma are GIVGSA, whereas the bees and Drosophila are GIVGGA.

\section{Amvasa expression in the postembryonic gonad and in adult somatic tissues}

Using specific primers we confirmed the presence of Amvasa transcripts in the ovaries of both castes of the honey bee throughout larval, pupal and imaginal development. Judging from band intensity, normalized against actin levels in the respective cDNA samples, the expression levels of vasa in ovaries of workers appear to be lower than in queens (Figure 2A). This observation is consistent with the differing dynamics of ovary development for the two castes (Hartfelder and Steinbrück, 1997). Amvasa transcript levels in the two castes showed little apparent modulation, suggesting that the gene is continuously expressed during postembryonic development of the gonads.

We next investigated whether Amvasa expression is gonad-specific. This analysis was conducted using RNA extracts from different body parts and organs of adult honey bee queens and workers. Apart from the expected expression in ovaries we could detect a faint but nevertheless clear Amvasa signal in dorsal fat body of queens (Figure 2B). Cloning and sequencing of this fragment confirmed that it was a bona fide vasa signal. We did not detect corresponding transcripts in fat body of workers, indicating pos- 
sible caste-specific regulation of Amvasa expression in this key metabolic tissue. For all other tissues tested in this study there was no evidence for Amvasa expression, underlining its possible role in germ line specification and gonadal activity.

\section{In situ detection of Amvasa transcripts in ovaries of honey bee queens and workers}

The localization of Amvasa transcripts was investigated by in situ hybridization using a digoxigenin-labeled riboprobe. The general spatial pattern of Amvasa expression was very similar for the two honey bee castes (Figures 3 and 4) and was little influenced by social condition. We compared ovaries from queens of different social status (virgin queens and mated, egg laying queens) and from workers kept

A
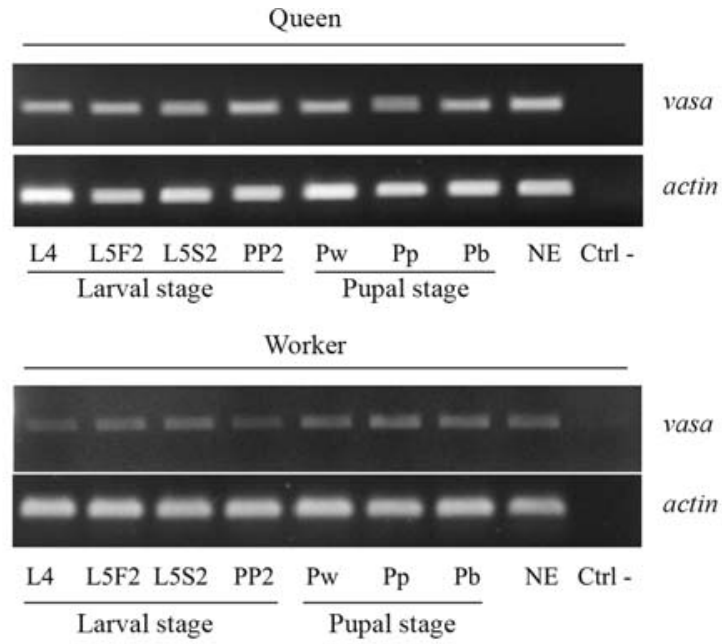

B
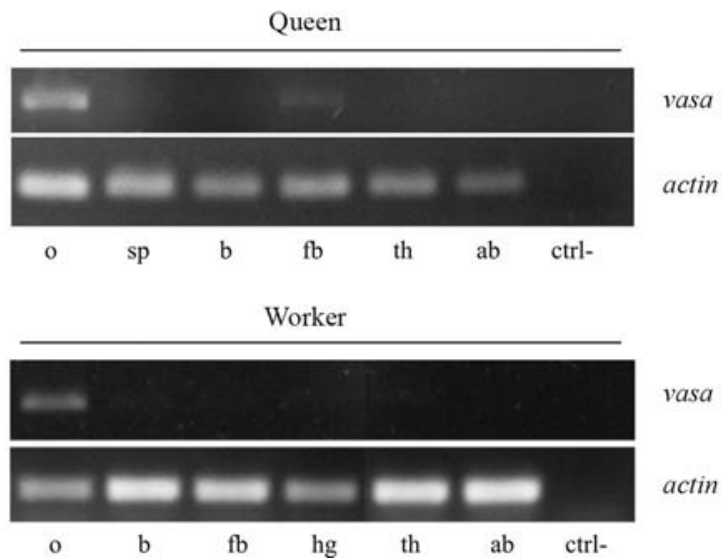

Figure 2 - RT-PCR detection of vasa expression in honey bees. (A) Expression profile in ovaries of honey bee queens and workers during postembryonic development. L4 - $4^{\text {th }}$ larval instar; L5F2 - $5^{\text {th }}$ larval instar, mid-feeding phase; L5S2 - $5^{\text {th }}$ larval instar, mid-spinning phase; PP2 mid-prepupal phase; $\mathrm{Pw}, \mathrm{Pp}, \mathrm{Pb}$ - white, pink and brown-eyed pupae, respectively; NE - newly emerged adult. Ctrl- - negative control, amplification without template. (B) Analysis of vasa expression in somatic tissues of adult queens and workers: o - ovary; $\mathrm{b}$ - brain; fb - fat body; th - thorax (dorsal tegument); $a b$ - abdomen (dorsal tegument); sp - spermatheca of queen; hg - hypopharyngeal gland of worker. ctrl- - negative control without template. actin - A. mellifera actin, used for normalization. under queenless conditions, remembering that ovary activation in honey bee workers only exceptionally occurs in the presence of the queen (Hartfelder and Engels, 1998; Barron and Oldroyd, 2001; Makert et al., 2006).

In ovaries of queenless workers, the onset of Amvasa expression was detected in the germarium (Figure 3A, B) at a position where early germ cell clusters consisting of 8-16 cells are formed (Tanaka and Hartfelder, 2004; Tanaka et al., 2006). This point is just below the transition zone from the terminal filament to the germarium, a zone where we could not detect Amvasa transcripts (Figure 3A, C). Beneath this transition zone, expression levels gradually appeared to increase in germ cells (Figure 3C). After separation of the follicles from the germarium, Amvasa transcripts were primarily detected in nurse cells (trophocytes) (Figure 3D). In the larger trophic chambers at the left side of this figure, a staining gradient indicated higher expression levels in basal nurse cells as compared to apical ones. In the egg chambers of these follicles, Amvasa transcripts only became visible as the oocytes started to increase in size (Figure 3D, E).

In situ hybridization experiments on queen ovarioles showed a similar picture, confirming that Amvasa transcript levels gradually increase as germ line cells pass from the upper to the lower germarium. Since the germaria of queen ovarioles are much longer than those of workers, we additionally observed that in the more basal parts of the germarium, Amvasa expression appeared to be highest in oocytes and/or the trophocytes closest to it (Figures 4A, D, $\mathrm{E})$. This is the region where oocyte-trophocyte complexes undergo a transformation from a cluster to a comet-like arrangement (Tanaka and Hartfelder, 2004).

As the follicles segregated from the germarium (arrow in Figure 4A) Amvasa transcript levels were still higher in the oocytic than in the trophic chamber. However, soon thereafter this picture changed and Amvasa expression appeared to be switched on in trophocytes, which, like in the workers, now showed higher and gradually increasing Amvasa transcript levels (Figures 4A, B). In egg chambers, a marked increase in Amvasa mRNA was only observed as they enlarged and reached about the same size as the corresponding trophic chambers (Figure 4C). A thin stream of Amvasa transcripts (arrow in Figure 4C) indicated that Amvasa mRNA may be transported from the trophic chamber to the oocytes across the trophocytic canal. This panel also illustrates the apparent restriction of Amvasa transcripts to germ line cells since follicle epithelial cells did not stain with the probe.

We next investigated more closely whether Amvasa transcripts may be present in terminal filaments of queen ovarioles. This was of interest because previous histological studies had indicated the possible presence of germ line stem cells in niches along the extensive terminal filaments of queen ovarioles (Gutzeit et al., 1993; Tanaka and Hartfelder, 2004). Even though we could detect the pres- 

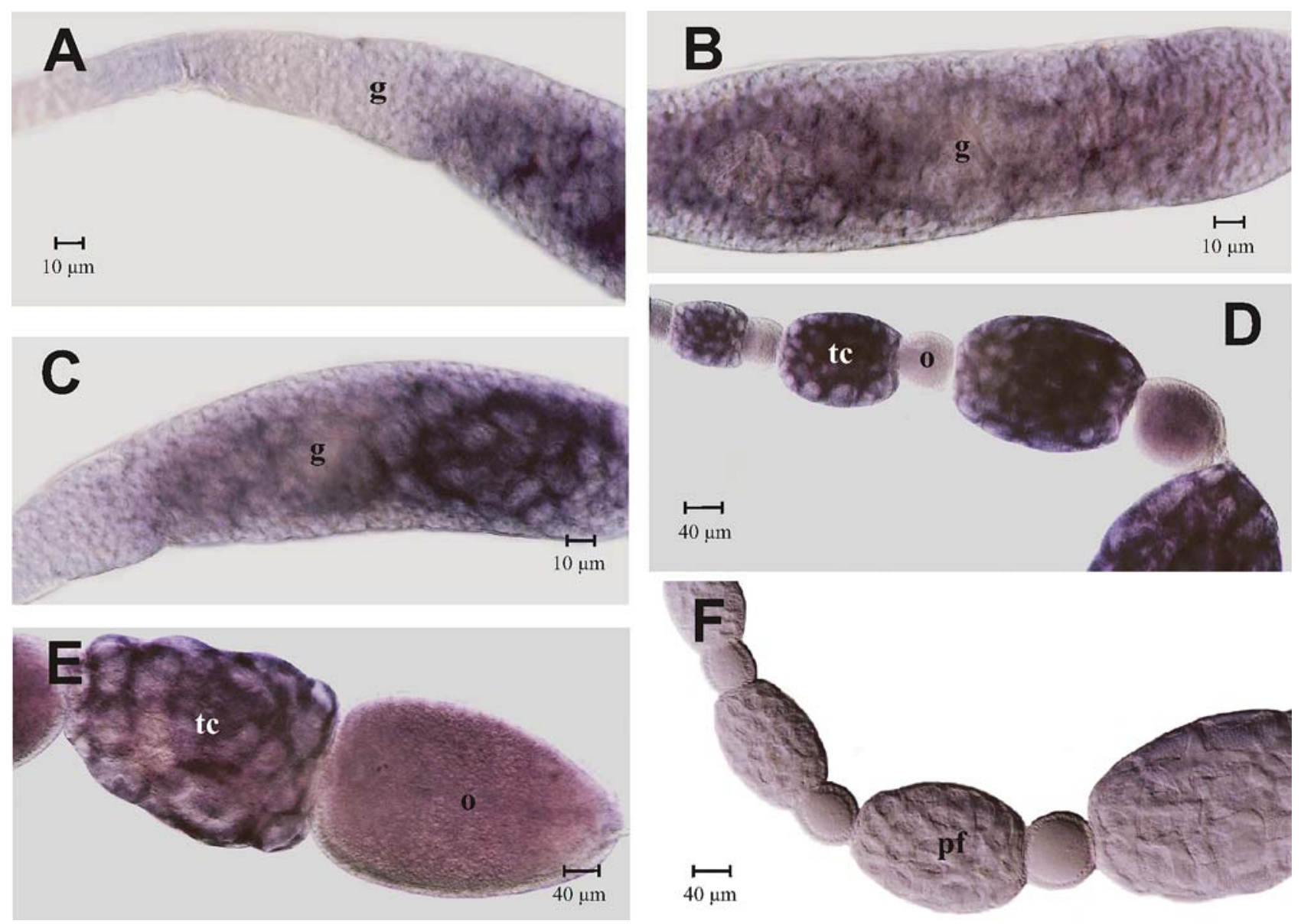

Figure 3 - Amvasa mRNA detection by in situ hybridization in ovarioles of queenless honey bee workers. Apical is to the left in all figures. (A, B and C) Amvasa expression visualized in germ line cells throughout the germarium. The Amvasa-negative area at the left of A and C is the transition zone from the terminal filament to the germarium. (D) Amvasa expression in previtellogenic follicles is prominent in the trophic chambers and only gradually increases in the growing oocytes. (E) In early vitellogenic follicles, Amvasa transcripts in the oocyte show a homogeneous distribution. Negative control with sense probe (F). g - germarium, o - oocyte, pf - previtellogenic follicle, tc - trophic chamber, tf - terminal filament.

ence of Amvasa transcripts in terminal filaments (Figure 5), this staining was rather diffuse and not constant. Especially, it did not allow us to distinguish between the rounded putative germ line cells and the flattened, disc-like somatic cells of the filaments. This finding is of interest because, as described above, we also could not detect Amvasa transcripts in the transition zone from the terminal filament to the top of the germarium (Figure 3A), where germ cells could be clearly identified by their general histology and cell division pattern (Tanaka and Hartfelder, 2004). This finding indicates that in the honey bee, vasa may not be a marker appropriate for germ line stem cells, but that vasa apparently becomes induced in the germ line only after cystocytes separate from the niche and begin to form the large germ cell clusters, typical of the polytrophic meroistic ovary type.

\section{In situ detection of vasa transcripts in ovaries of the stingless bee Melipona quadrifasciata}

The high degree in sequence identity made it possible to use the Amvasa probe for in situ hybridization experi- ments on ovarioles of the stingless bee, M. quadrifasciata. This probe detected vasa transcripts throughout the entire length of the ovarioles of stingless bee queens. Like in the honey bee, vasa transcript levels gradually increased along the germarium accompanying oogenesis progression (Figure $6 \mathrm{~A}-\mathrm{C}$ ). However, as the follicles separated from the germarium, the timing of vasa expression in the stingless bee seemed to differ from the pattern observed in the honey bee. In the honey bee, Amvasa transcript levels were initially higher in the oocyte, but subsequently Amvasa expression became strongly turned on in the trophocytes, and only later did its transcript levels gradually increase again in the oocyte. In contrast to this, we noted that vasa transcript levels in the stingless bee ovary were continuously higher in the oocytes, already from the start of follicle growth (Figure 6D). This difference in the localization of a presumably important component for germ line function is of interest as it may represent a molecular corollary to the morphological differences between A. mellifera and $M$. quadrifasciata ovarioles (Tanaka et al., 2009). 

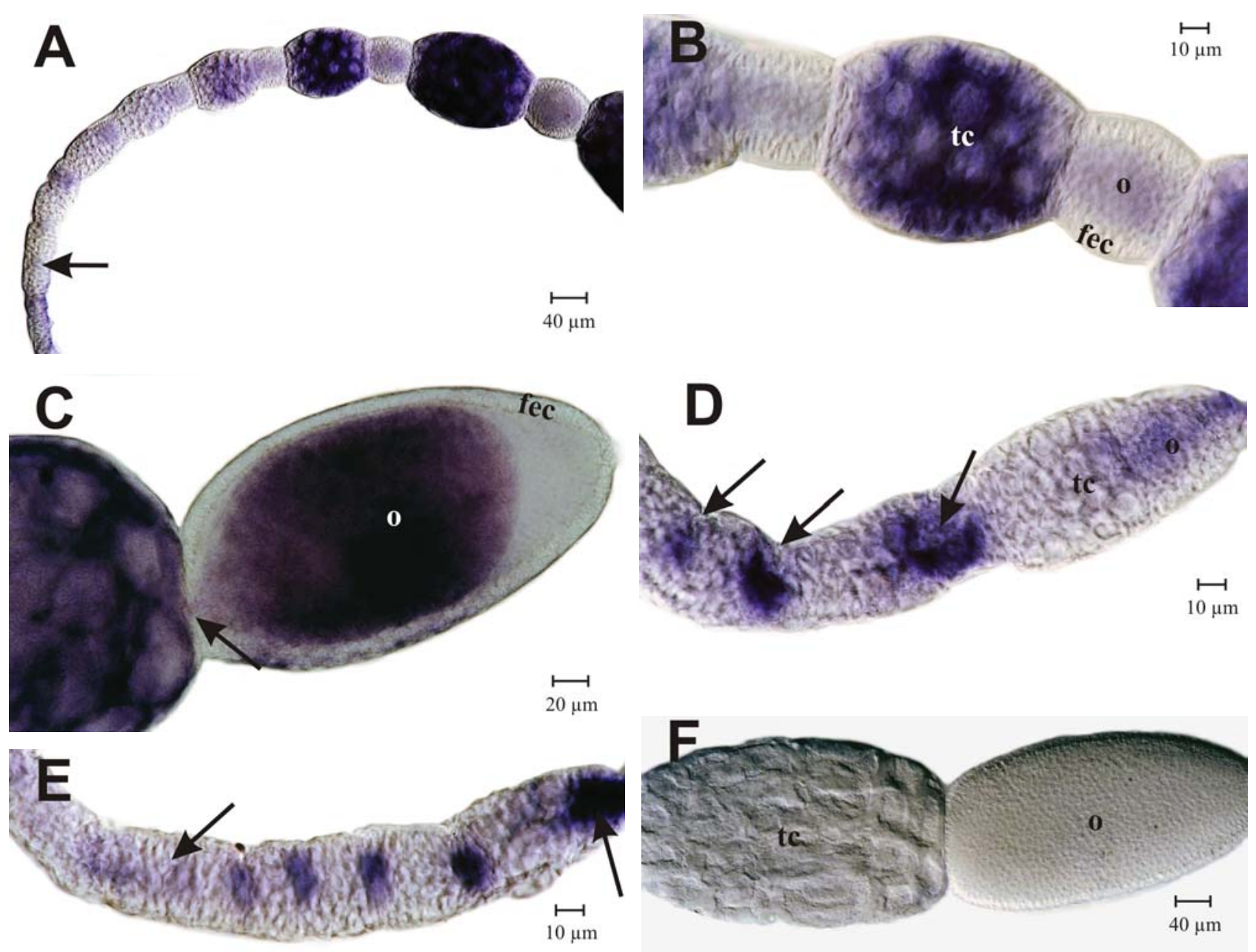

Figure 4 - Amvasa mRNA detection by in situ hybridization in ovarioles of mated (A, B, C) and virgin queens (D, E) of A. mellifera. Shortly after follicles segregated from the germarium, vasa transcripts were visible primarily in oocytes (A, D, E, arrows). As the previtellogenic follicles matured, Amvasa expression was switched on and strongly increased in the trophocytes (A, B). In these follicles, Amvasa mRNA appeared to be transported into the oocyte across the trophocytic canal (C, arrow), gradually dispersing in the oocyte cytoplasm. (F) Negative control with sense probe. fec - follicular epithelium cells, o - oocyte, tc - trophic chamber.

\section{Discussion}

Molecular analysis of the vasa orthologs of the honey bee and stingless bees

The predicted amino acid sequence of the Apis mellifera Vasa protein contained all the diagnostic motifs of DEAD-box helicases, but differed in two puzzling aspects from Vasa proteins of other insects. Most notably, the ARKF motif, which is considered a diagnostic motif of the Vasa family, had changed to IVKF (Chang et al., 2002). Similar alterations in this motif had previously been reported for the parasitic wasp, Copidosoma floridanum (Donnell et al., 2004), the red flour beetle Tribolium castaneum (Lorenzen et al., 2005) and also for other organisms (Sagawa et al., 2005; Ohashi et al., 2007). The function of the ARKF domain is not clear yet, and alterations in this motif do not seem to interfere with the ATPase or helicase activities of Vasa proteins (Sagawa et al., 2005; Schröder, 2006; Ohashi et al., 2007).

Another difference between honey bee Vasa and its orthologs in other insects concerns the reduction in Nterminal RGG repeats. RGG motifs in human hnRNP U protein have been shown to bind RNA (Kiledjian and Dreyfuss, 1992). This function could be important in the organization of specific RNA complexes at the posterior egg pole when polar granules are formed (Hay et al., 1988), even though the localization of Vasa itself to the posterior pole appears to be independent of its RNA binding capacity (Liang et al., 1994).

Sequencing of vasa orthologs of four stingless bee species showed that the change from ARKF to an IVKF motif and the reduction in RGG repeats is shared by the two tribes Apini and Meliponini. These modifications in an otherwise highly conserved protein, thus, appear to predate the split between the two tribes of highly eusocial bees. Especially in the light of recent molecular phylogenies of the en- 


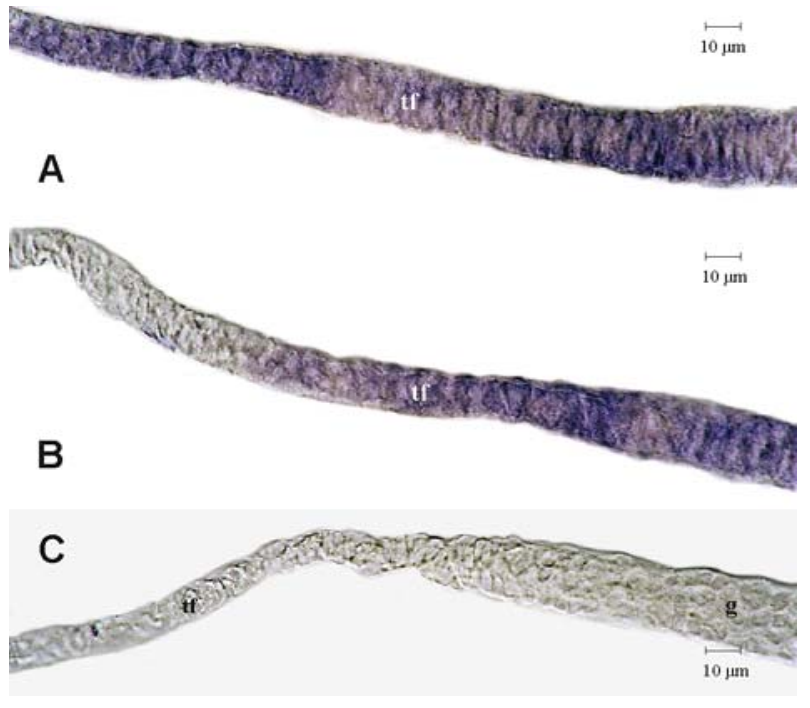

Figure 5 - Amvasa mRNA detection by in situ hybridization on terminal filaments of ovarioles of mated queens. (A, B) Labeling for the germ line marker Amvasa was diffuse and variable in this region and, while indicating the presence germ cells, it did not allow distinguishing between disc-like somatic cells and rounded putative germ line stem cells. (C) Negative control with sense probe. $\mathrm{g}$ - germarium, tf - terminal filament.

tire clade Apinae (Kawakita et al., 2008; Whitfield et al., 2008), they could actually represent an ancestral trait in the corbiculate bees, predating the evolution of sociality in this group. Confirming this hypothesis will, however, require sequencing of vasa orthologs in bumble bees (Bombini) and orchid bees (Euglossini).

The cladogram for the hymenopteran vasa orthologs further underlines the high degree in similarity for this gene in the two tribes of highly eusocial bees and sets them clearly apart from parasitic wasps. The fact that the two species of the genus Melipona cluster together is not surprising. The split between these and the two other stingless bee species ( $S$. postica and $F$. varia), however is of interest. The latter two species are traditionally included within the trigonines, a grouping of several hundred stingless bee species (Camargo and Pedro, 2007). The two groups differ with respect to the mechanism of caste determination (Kerr, 1950; Hartfelder et al., 2006).

\section{Developmental profiling and tissue specificity of vasa expression in honey bees}

The results of this qualitative analysis showed that Amvasa is expressed continuously and at apparently constant levels in the developing gonads of both queens and workers during the late larval stages (fourth and fifth instar) and during pupal development. Interestingly, the expression levels seem to be higher in queens than in workers, and this aspect certainly deserves a closer look using a quantitative RT-PCR approach. The observed caste differences might be related to the divergence in ovary development, particularly in the fifth instar which is marked by massive cell death in the ovaries of worker larvae (Hartfelder and Steinbrück, 1997; Schmidt-Capella and Hartfelder, 1998, 2002), considerably reducing the number of germ line cells.

The above described differences in amino acid sequence between honey bee Vasa and its orthologs in other insects made us ask whether this may be reflected in altered tissue specificity of vasa expression. Besides the clear and expected signal obtained for ovaries of adult queens and workers, we also found evidence for a low, yet clearly detectable level of vasa expression in fat body of honey bee queens. Since none of the other tissues showed such a signal, and since it was found in queen fat body only, we con-
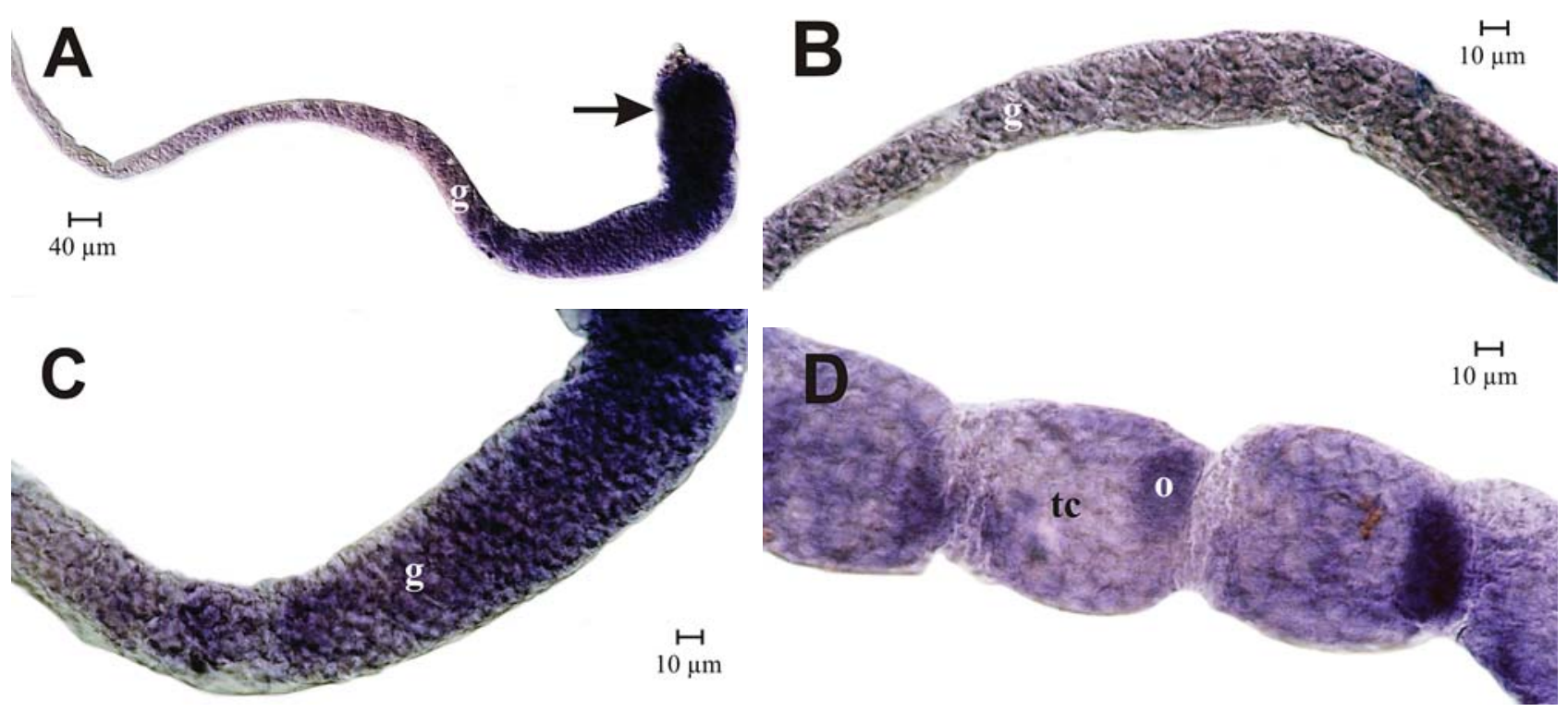

Figure 6 - In situ hybridization with a honey bee vasa probe on ovarioles of queens of the stingless bee Melipona quadrifasciata. (A, B, C) vasa mRNA was detected in germ line cells throughout the germarium. (D) In previtellogenic follicles, vasa transcript levels in oocytes were higher than those seen in the corresponding trophic chambers (see also follicle marked by arrow in A). $\mathrm{g}$ - germarium, o - oocyte, tc - trophic chamber. 
clude that this is a relevant non-germ line expression, specific to the fat body of the reproductive caste. Knowingly, the fat body plays a major role in controlling fertility of queens and workers by its output of vitellogenin, the major yolk protein precursor. Honey bee queens are notorious for their extremely high hemolymph vitellogenin titers (Engels, 1974; Hartfelder and Engels, 1998), and the fat body is the major site of vitellogenin gene expression (Piulachs et al., 2003). The finding of a vasa expression signal in queen fat body could, thus, provide a link between the previtellogenic and vitellogenic phases of follicle development.

Extra-gonadal expression of vasa is, however, neither a novel finding nor a unique one specific to honey bees. Vasa protein and/or vasa mRNA have, for example, already been detected in embryonic somatic cells of Xenopus laevis (Ikenishi and Tanaka, 2000), in polychaetes (Rebscher et al., 2007), and in ectodermal epithelial cells of cnidarians (Mochizuki et al., 2001). In honey bee embryos, a group of cells in the mandibular segment has been shown to express Amvasa (Dearden, 2006).

\section{In situ localization of vasa mRNA in the ovaries of highly eusocial bees}

The detection of Amvasa mRNA throughout the germarium and in the cytoplasm of nurse cells and oocytes of follicles confirmed the expected association of Amvasa expression with germ line cells. Besides detecting an oocytic vasa mRNA signal in the lower germarium and in early follicles as they segregated from the germarium, we also found evidence for Amvasa expression in cells composing the terminal filaments. Divergence from the fly model of oogenesis (Bastock and St Johnston, 2008) in these two aspects raises the question as to whether honey bees may differ from Drosophila in pathways involving Vasa function(s). In fly oogenesis, vasa transcription depends on the prior localization of oskar mRNA to the posterior pole, and Oskar protein then remains associated with the germ line determining pole plasm (Rongo and Lehmann, 1996). In turn, Vasa protein is necessary for the localized translation of nanos mRNA (Gavis et al., 1996) and for the localization of other gene products, including gurken mRNA, which is involved in the establishment of the two major oocyte and, consequently, embryonic axes (Tinker et al., 1998). Since in the honey bee genome neither gurken nor oskar orthologs were found (The Honey Bee Genome Sequencing Consortium, 2006), but a clear ortholog of nanos, it is quite possible that embryonic axis specification and germ line determination in the honey bee follows a different route from that established for the fly. Interestingly, gurken, oskar and bicoid are also missing in the Bombyx mori and Tribolium castaneum genomes (Dearden et al., 2006; Schröder, 2006) and, like in the honey bee, in neither of these species differentiated pole cells were evidenced (Nakao, 1999; Handel et al., 2000). In the honey bee, germ line cells seem to be formed by an in- ductive event late in embryogenesis (Dearden, 2006; Fleig and Sander, 1998), as is the case in most metazoans (Extavour and Akam, 2003). Whether and how the early appearance of Amvasa mRNA in oocytes and trophocytes may be related to the determination of germ line cells, needs further investigation, especially as to how vasa expression may be connected to downstream events, such as the translation of nanos mRNA in honey bee eggs.

The detection by in situ hybridization of Amvasa transcripts in the terminal filament region is another clear difference to Drosophila, but actually did not come as a surprise. The ovarioles of Apis mellifera queens and workers have enormously elongated terminal filaments, and these house two cell types. Interspersed between the flattened somatic cells organized in stack-of-coins arrangements are clusters of rounded cells with large nuclei and weakly staining cytoplasm. Being mitotically active (Tanaka and Hartfelder, 2004), they show a set of characteristics normally attributed to primordial germ line cells (Mahowald, 1962; Wolf et al., 1983). In contrast, terminal filaments in the Drosophila ovary are short and made up of disk-like somatic cells only. Apart from tethering together the ovarioles, an important function of the terminal filament is to form a cap structure that, in Drosophila, provides a niche environment around the 2-3 germ line stem cells (Lin and Spradling, 1993; Zhang and Kalderon, 2000; Morrison and Spradling, 2008). For sustaining high egg-laying rates, such as observed for honey bee queens, a system of 2-3 stem cells in a niche would probably be insufficient. Clusters of germ-line stem cells in elongated terminal filaments could, thus, be a solution to this problem. The rather diffuse pattern of Amvasa staining over the terminal filaments, however, did not permit to definitively distinguish somatic from putative germ line cells. But while this would be in accordance with epigenetic inductive events that might progressively separate germ line from somatic cells (Extavour, 2007), it is still unclear as to how such germ line cells in the terminal filament would make their way down into the germarium.

The spatial pattern of vasa expression observed in honey bee ovarioles was very similar to that seen in the stingless bee Melipona quadrifasciata. Also in this species, vasa transcript levels were observed to gradually increase along the apical-basal axis of the germarium, and vasa mRNA was also detected in early follicles and seen to accumulate in oocytes. These findings are of interest because, together with the close vasa sequence similarity for the two groups of highly eusocial bees, they provide a unifying theme for oogenesis in these bees, inspite of their differences in ovariole structure (Tanaka et al., 2009) and in reproductive biology. This difference resides primarily in the ovarian activity of stingless bee workers which may produce both reproductive and trophic eggs (for review see Hartfelder et al., 2006). 
Our findings on vasa expression in social bees are in accordance with a recent study on vasa and nanos expression in ants (Khila and Abouheif, 2008), where Vasa protein was also detected in oocytes which were still in the germarium and in follicles that had separated from it. In ant species where workers produce two types of eggs, as do stingless bee workers, nanos mRNA appeared concentrated in a spot that colocalized with Vasa protein. In eggs with reproductive potential, this spot stayed associated with the posterior oocyte pole. In contrast, Vasa protein, and consequently also nanos mRNA, apparently failed to localize to the posterior pole in the non-viable trophic eggs. Khila and Abouheif (2008) consider that this mislocalization of two crucial posterior pole components observed in trophic eggs could represent a developmental mechanism that generates reproductive constraint in the worker caste and, thus, would represent an important factor in social evolution in the Hymenoptera. Obviously, this is an interesting hypothesis with wide ranging implications on the expression patterns of genes underlying developmental patterning mechanisms. The question is, how and to what extent these genes may have also been co-opted to generate evolutionarily stable differences in the reproductive potential of females in the caste phenotypes of other social Hymenoptera, such as wasps and bees.

\section{Acknowledgments}

We thank Luis Roberto Aguiar and Weyder Cristiano Santana for assistance in maintaining the bee colonies. Financial support was provided by the Fundação de Amparo à Pesquisa do Estado de São Paulo (FAPESP grants 99/00719-6 and 02/11729-7).

\section{References}

Barron AB and Oldroyd BP (2001) Social regulation of ovary activation in 'anarchistic' honey bees (Apis mellifera). Behav Ecol Sociobiol 49:214-219.

Bastock R and St Johnston D (2008) Drosophila oogenesis. Curr Biol 18:1082-1087.

Boleli IC, Simões ZLP and Bitondi MMG (1999) Cell death in ovarioles causes permanent sterility in Frieseomelitta varia workers bees. J Morphol 242:271-282.

Camargo JMF and Pedro SRM (2007) Meliponini Lepeletier, 1936. In: Moure JS, Urban D and Melo GAR (eds) Catalogue of Bees (Hymenoptera, Apoidea) in the Neotropical Region. Sociedade Brasileira de Entomologia, Curitiba, pp 272-578.

Chang C, Dearden PK and Akam M (2002) Germ line development in the grasshopper Schistocerca gregaria. Dev Biol 252:100-118.

Cruz-Landim C, Reginato RD and Imperatriz-Fonseca VL (1998) Variation in ovariole number in Meliponinae (Hymenoptera, Apidae) queen's ovaries, with comments on ovary development and caste differentiation. Pap Avulsos Zool S Paulo 40:289-296. de Cuevas M, Lilly MA and Spradling AC (1997) Germline cyst formation in Drosophila. Annu Rev Genet 31:405-428.

Dearden PK (2006) Germ cell development in the honeybee (Apis mellifera): Vasa and Nanos expression. BMC Dev Biol 6:1-14.

Dearden PK, Wilson MJ, Sablan L, Osborne PW, Havler M, McNaughton E, Kimura K, Milshina NV, Hasselmann M, Gempre T, et al. (2006) Patterns of conservation and change in honey bee developmental genes. Genome Res 16:13761384.

Donnell DM, Corley LS, Chen G and Strand MR (2004) Caste determination in a polyembryonic wasp involves inheritance of germ cells. Proc Natl Acad Sci USA 101:10095-10100.

Engels W (1974) Occurrence and significance of vitellogenins in female castes of social Hymenoptera. Am Zool 14:12291237.

Extavour C (2007) Evolution of the bilaterian germ line: Lineage origin and modulation of specification mechanisms. Integr Comp Biol 47:770-785.

Extavour C and Akam ME (2003) Mechanisms of germ cell specification across the metazoans: Epigenesis and preformation. Development 130:5869-5884.

Findley SD, Tamanaha M, Clegg NJ and Ruohola-Baker H (2003) Maelstrom, a Drosophila spindle-class gene, encodes a protein that colocalizes with Vasa and RDE1/AGO1 homolog, Aubergine, in nuage. Development 130:859-871.

Fleig R and Sander K (1998) Honeybee morphogenesis, embryonic cell movements that shape the larval body. Development 103:525-534.

Fujiwara Y, Komiya T, Kawabata H, Sato M, Fujimoto H, Furusawa M and Noce T (1994) Isolation of a DEAD-family protein gene that encodes a murine homologue of Drosophila vasa and its specific expression in germ cell lineage. Proc Natl Acad Sci USA 91:12258-12262.

Gavis ER, Lunsford L, Bergsten SE and Lehmann R (1996) A conserved 90 nucleotide element mediates translational repression of nanos RNA. Development 122:2791-2800.

Gilboa L and Lehmann R (2004) How different is Venus from Mars? The genetics of germ-line stem cells in Drosophila females and males. Development 131:4895-4905.

Gruidl M, Smith PA, Kuznicki KA, McCrone JS, Kirchner J, Roussell DL, Strome S and Benett KL (1996) Multiple potential germ-line helicases are components of the germline-specific P granules of Caenorhabditis elegans. Proc Natl Acad Sci USA 93:13837-13842.

Guidugli-Lazzarini KR, Nascimento AM, Tanaka ED, Piulachs MD, Hartfelder K, Bitondi MMG and Simoes ZLP (2008) Expression analysis of putative vitellogenin and lipophorin receptors in honey bee (Apis mellifera L.) queens and workers. J Insect Physiol 54:1138-1147.

Gutzeit HO, Zissler D and Fleig R (1993) Oogenesis in the honeybee Apis mellifera: Cytological observations on the formation and differentiation of previtellogenic ovarian follicles. Roux's Arch Dev Biol 202:181-191.

Handel K, Grünfelder CG, Roth S and Sander K (2000) Tribolium embryogenesis: A SEM study of cell shapes and movements from blastoderm to serosal closure. Dev Genes Evol 210:167-179.

Hartfelder K and Engels W (1992) Allometric and multivariate analysis of sex and caste polymorphism in the neotropical 
stingless bee, Scaptotrigona postica. Insectes Soc 39:251266.

Hartfelder K and Engels W (1998) Social insect polymorphism: Hormonal regulation of plasticity in development and reproduction in the honeybee. Curr Topics Dev Biol 40:45-77.

Hartfelder K, Makert GR, Judice CC, Pereira GAG, Santana WC, Dallacqua R and Bitondi MMG (2006) Physiological and genetic mechanisms underlying caste development, reproduction and division of labor in stingless bees. Apidologie 37:144-163.

Hartfelder K and Steinbrück G (1997) Germ cell cluster formation and cell death are alternatives in caste-specific differentiation of the larval honey bee ovary. Invertebr Reprod Dev 31:237-250.

Hay B, Jan LY and Jan YN (1988) A protein component of Drosophila polar granules is encoded by vasa and has extensive sequence similarity to ATP-dependent helicases. Cell 55:577-587.

Ikenishi K and Tanaka T (2000) Spatio-temporal expression of Xenopus vasa homolog, XVLG1, in oocytes and embryos: The presence of $X V L G 1$ RNA in somatic cells as well as germline cells. Dev Growth Diff 42:95-103.

Imperatriz-Fonseca VL and Kleinert ADP (1998) Worker reproduction in the stingless bee species Friesella schrottkyi (Hymenoptera, Apidae, Meliponinae). Entomol Gener Appl 23:169-175.

Kawakita A, Ascher JS, Sota T, Kato M and Roubik DW (2008) Phylogenetic analysis of the corbiculate bee tribes based on 12 nuclear protein-coding genes (Hymenoptera, Apoidea, Apidae). Apidologie 39:163-175.

Kerr WE (1950) Genetic determination of castes in the genus Melipona. Genetics 35:143-152.

Khila A and Abouheif E (2008) Reproductive constraint is a developmental mechanism that maintains social harmony in advanced ant societies. Proc Natl Acad Sci USA 105:17884-17889.

Kiledjian M and Dreyfuss G (1992) Primary structure and binding activity of the hnRNP U protein: Binding RNA through RGG box. EMBO J 11:2655-2664.

King RC (1970) Ovarian Development in Drosophila melanogaster. Academic Press, New York, 227 pp.

Kumar S, Tamura K and Nei M (2004) MEGA3: Integrated software for Molecular Evolutionary Genetics Analysis and sequence alignment. Brief Bioinform 5:150-163.

Liang L, Diehl-Jones W and Lasko PF (1994) Localization of Vasa protein to the Drosophila pole plasm is independent of its RNA-binding and helicase activities. Development 120:1201-1211.

Lin H and Spradling AC (1993) Germline stem cell division and egg chamber development in transplanted Drosophila germaria. Dev Biol 159:140-152.

Lorenzen MD, Doyungan Z, Savard J, Snow K, Crumly LR, Shippy TD, Stuart JJ, Brown SJ and Beeman RW (2005) Genetic linkage maps of the red flour beetle, Tribolium castaneum, based on bacterial artificial chromosomes and expressed sequence tags. Genetics 170:741-747.

Lourenço AP, Mackert A, Cristino AS and Simoes ZLP (2008) Validation of reference genes for gene expression studies in the honey bee, Apis mellifera, by quantitative real-time RT-PCR. Apidologie 39:372-385.
Mahowald AP (1962) Fine structure of pole cell and polar granules in Drosophila melanogaster. J Exp Zool 151:201-215.

Makert GR, Paxton RJ and Hartfelder K (2006) Ovariole number a predictor of differential success among worker subfamilies in queenless honeybee (Apis mellifera L.) colonies. Behav Ecol Sociobiol 60:815-825.

Michelette ERD and Soares AEE (1993) Characterization of preimaginal developmental stages in Africanized honey bee workers (Apis mellifera L.). Apidologie 24:431-440.

Michener CD (2000) The Bees of the World. John Hopkins University Press, Baltimore, 913 pp.

Mochizuki K, Nishimiya-Fujisawa C and Fujisawa T (2001) Universal occurrence of the vasa-related genes among metazoans and their germline expression in Hydra. Dev Genes Evol 211:299-308.

Morrison SJ and Spradling AC (2008) Stem cells and niches: Mechanisms that promote stem cell maintenance throughout life. Cell 132:598-611.

Nakao H (1999) Isolation and characterization of a Bombyx vasalike gene. Dev Genes Evol 209:312-316.

Ohashi H, Umeda N, Hirazawa N, Ozaki Y, Miura C and Miura T (2007) Expression of vasa (vas)-related genes in germ cells and specific interference with gene functions by doublestranded RNA in the monogenean Neobenedenia girellae. Int J Parasitol 37:515-523.

Olsen LC, Aasland R and Fjose A (1997) A vasa-like gene in zebrafish identifies putative primordial germ cells. Mech Dev 66:95-105.

Osborne PW and Dearden PK (2005) Non-radioactive in situ hybridization to honeybee embryos and ovaries. Apidologie 36:113-118.

Piulachs MD, Guidugli KR, Barchuk AR, Cruz J, Simoes ZLP and Belles X (2003) The vitellogenin gene of the honey bee, Apis mellifera: Structural analysis of the cDNA and expression studies. Insect Biochem Mol Biol 33:459-465.

Pyle AM (2008) Translocation and unwinding mechanisms of RNA and DNA helicases. Annu Rev Biophys 37:317-336.

Rachinsky A and Hartfelder K (1998) In vitro biosynthesis of juvenile hormone in larval honey bees: Comparison of six media. In Vitro Cell Dev Biol - Animal 34:646-648.

Rebscher N, Zelada-González F, Banish TU, Raible F and Arendt D (2007) Vasa unveils a common origin of germ cells and of somatic stem cells from the posterior growth zone in the polychaete Platynereis dumerilii. Dev Biol 306:599-611.

Rongo C and Lehmann L (1996) Regulated synthesis, transport and assembly of the Drosophila germ plasm. Trends Genet 12:102-109.

Sagawa K, Yamagata H and Shiga Y (2005) Exploring embryonic germ line development in the water flea, Daphnia magna, by zinc-finger-containing VASA as a marker. Gene Expr Patterns 5:669-678.

Saitou N and Nei M (1987) The neighbor-joining method: A new method for reconstructing phylogenetic trees. Mol Biol Evol 4:406-425.

Sakagami SF (1982) Stingless bees. In: Hermann HR (ed) Social Insects. Academic Press, New York, pp 361-423.

Sano H, Nakamura A and Kobayashi S (2002) Identification of a transcriptional regulatory region for germline-specific expression of vasa gene in Drosophila melanogaster. Mech Dev 112:129-139. 
Schmidt-Capella IC and Hartfelder K (1998) Juvenile hormone effect on DNA synthesis and apoptosis in caste-specific differentiation of the larval honey bee (Apis mellifera L.) ovary. J Insect Physiol 44:385-391.

Schmidt-Capella IC and Hartfelder K (2002) Juvenile-hormonedependent interaction of actin and spectrin is crucial for polymorphic differentiation of the larval honey bee ovary. Cell Tissue Res 307:265-272.

Schröder R (2006) vasa mRNA accumulates at the posterior pole during blastoderm formation in the flour beetle Tribolium castaneum. Dev Genes Evol 261:277-283.

Shibata N, Umesono Y, Orii H, Sakurai T, Watanabe K and Agata $\mathrm{K}$ (1999) Expression of vasa (vas)-related genes in germline cells and totipotent somatic stem cells of planarians. Dev Biol 206:73-87.

Snodgrass RE (1956) Anatomy of the Honey Bee. Cornell University Press, Ithaca, $334 \mathrm{pp}$.

Tanaka ED and Hartfelder K (2004) The initial stages of oogenesis and their relation to differential fertility in the honey bee (Apis mellifera) castes. Arthropod Struct Dev 33:431442 .

Tanaka ED, Schmidt-Capella IC and Hartfelder K (2006) Cell death in the germline - mechanisms and consequences for reproductive plasticity in social bees. Braz J Morph Sci 23:15-26.

Tanaka ED, Santana WC and Hartfelder K (2009) Ovariole structure and oogenesis in queens and workers of the stingless bee Melipona quadrifasciata (Hymenoptera, Apidae, Meliponini) kept under different social conditions. Apidologie 40:163-177.

The Honey Bee Genome Sequencing Consortium (2006) Insights into social insects from the genome of the honeybee Apis mellifera. Nature 443:931-949.
Tinker R, Silver D and Montell DJ (1998) Requirement for the vasa RNA helicase in gurken mRNA localization. Dev Biol 199:1-10.

Visscher PK and Dukas R (1995) Honeybees recognize development of nestmates ovaries. Anim Behav 49:542-544.

Waldschmidt AM and Campos LAO (1997) Behavioral plasticity of Melipona quadrifasciata (Hymenoptera, Meliponinae). Rev Brasil Biol 58:25-31.

Whitfield JB, Cameron SA, Huson DH and Steel. MA (2008) Filtered Z-closure supernetworks for extracting and visualizing recurrent signal from incongruent gene trees. Syst Biol 57:939-947.

Wolf N, Priess J and Hirsh D (1983) Segregation of germline granules in early embryos of Caenorhabditis elegans: An electron microscopic analysis. J Embryol Exp Morphol 73:297-306.

Zhang Y and Kalderon D (2000) Regulation of cell proliferation and patterning in Drosophila oogenesis by Hedgehog signaling. Development 127:2165-2176.

\section{Supplementary Material}

The following online material is available for this article:

Figure S1 - ClustalW alignment of insect Vasa protein sequences.

Figure S2 - ClustalW alignment of hymenopteran Vasa protein sequences, with Drosophila Vasa as outgroup.

Associate Editor: André Luiz Paranhos Perondini

License information: This is an open-access article distributed under the terms of the Creative Commons Attribution License, which permits unrestricted use, distribution, and reproduction in any medium, provided the original work is properly cited. 

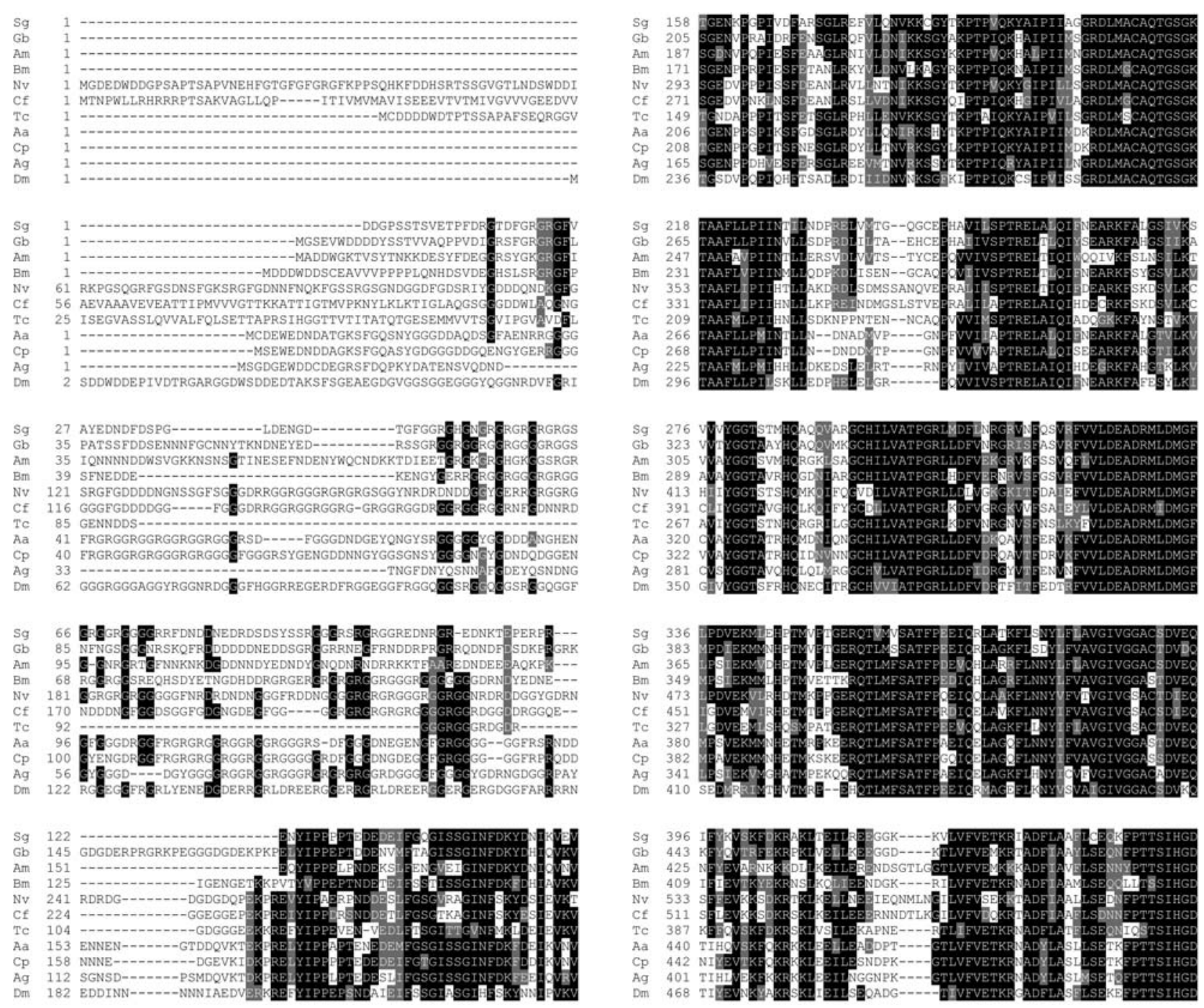

Figure S1 - ClustalW alignment of insect Vasa protein sequences.
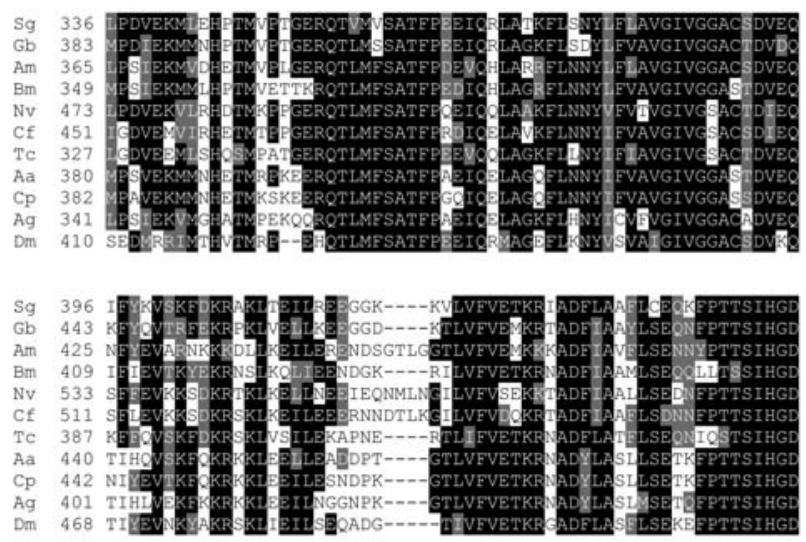

Figure S1 - (cont.) 

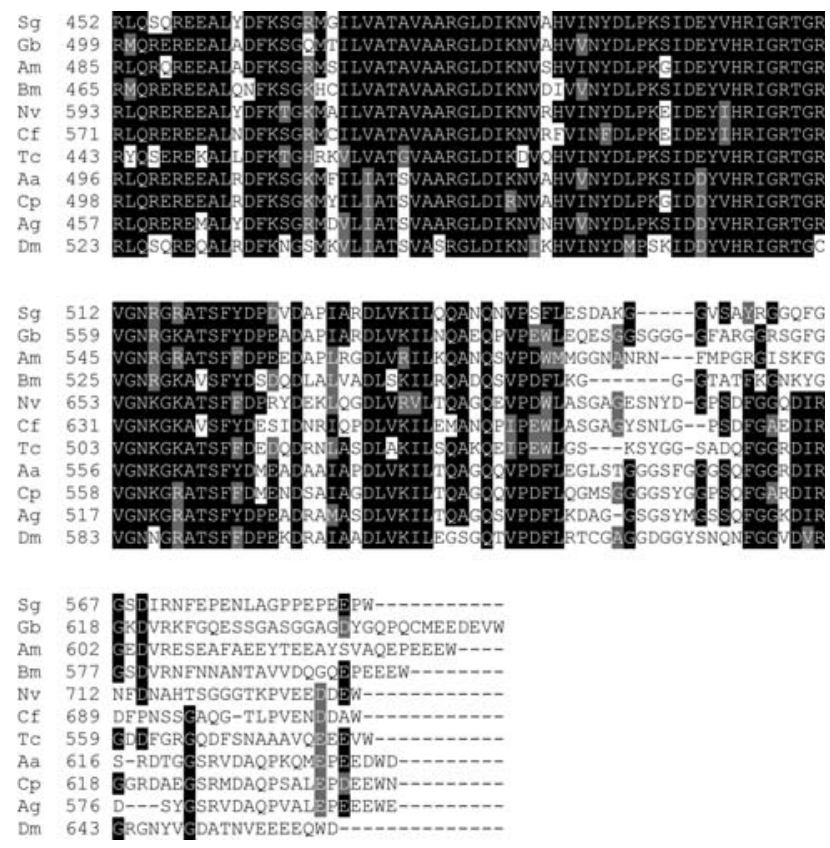

Figure S1 - (cont.) 
MGDEDWDDGPSAPTSAPVNEHFGTGFGFGRGFKPPSQHKFDDHSRTSSGVGTLNDSWDDIRKPGSQGRFGSDNSFGKSRGFGDNNFNQKFGSSRGSGNDGGDEGDSRIYGDDDQNDKGFG MTNPWLLRHRRRPTSAKVAGLLQP_-..-ITIVMVMAVI SEEEVTVTMIVGVVVGEEDVVAEVAAAVEVEATTI PMVVVGTTKKATT IGTMVPKNYLKLKTIGLAQGSGGGDDWLAQGNG . MADDGKTVSYTNKKDESYFDEGGRSYGKGRGFIIQNNNNDDWSVGKKNSNSGIINESEFND

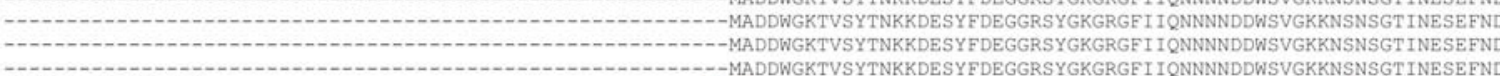

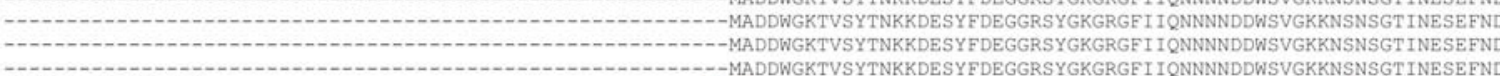
-MSDDWDDEPIVDTRG-

SRGFGDDDDNGNSSGFSGGGDRRGGRGGGRGRGRGSGGYNRDRDNDDGGYGERRGRGGRGGGRGRGRGGGGGFNRDRDNDNGGGFRDDNGGGGRGRGRGGGRGGRGGNRDRDDGGYGDRN GGGFGDDDGG----FGGGDRRGRGGRGGRG-GRGGRGGDRGGRGGRGGRNFDNNRDNDDDNGFGGDSGGFGDGNGDEGFGG----GGRGRGRGRGRGGGGRGGRDGGDRGGQE--

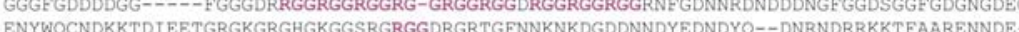

ENYWOCNDKKTDIEETGRGKGRGHGKGGSRGRGGDRGRTGFNNKNKDGDDNNDYEDNDYO--DNRNDRRKKTFAARENNDEENYWONDKKTDIEETGRGKGRGHGKGGSRGRGGDRGRTG FNMNKDGDDNNDYEDNDYQ-DNRNDRRKKTFARENNDE- ENYWQCNDKKTDIEETGRGKGRGHGKGGSRGRGGNRGRTGFNNKNKDGDDNNDYEDNDYQ--DNRNDRRKKTFAAREDNDE- ENYWQCNDKKTDIEETGRGKGRGHGKGGSRGRGGNRGRTGFNNKNKDGDDNNDYEDNDYQ--DNRNDRRKKTFAAREDNDE--- -

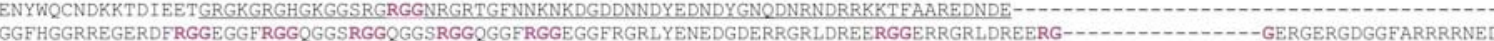
.

RDRDGDGDGDQPEKPREVYI PAERPNDDESLFGSGVRAGINFSKYDSIEVKTSGEDVPPPISSFDEANLRVLLNT'NI KKSGYTKPTPVQKYGIPILLSGRDLMACAQTGSGKTAAFLIPI -

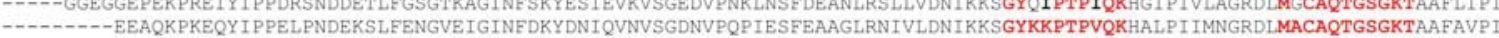
- EEAQKPKEQYIPPELPNDERSLFENGVEIGINF DKYDNIQVNVSGDNVPQPIESFEAAGLRNIVLDNIKKSGYKKPTPVQKHALPIIMNGRDLMACAQTGSGKTAAFAVPI -EAQKRKEQYIPPELPNDEKSLFENGVEIGINFDKYDNIQVNVSGDNVPQPIESFEAAGLRNIVLDNI KKSGYKKPTPVQKHALPI IMNGRDIMACAQTGSGKTAAFAVPI -GERKREYIPPELPNDEKSLFENGVEIGINFDKYDNIQVNVSGDNVPQPIESFEAAGLRNIVLDNIKKSGYKRTPVQKHALPI IMNGRDLMACAQTGSGKTAAFAVPI DINNNNNI AEDVERKREFYIPPEPSNDAIEIFSSGIASGIHESKYNNIPVKVTGSDVPOPIOHETSADLRDIIIDNVNKSGEKIPTPIQKCSIPVISSGRDLMACAQTGSGKTAAFLLP

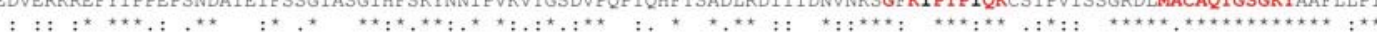

IHTLLAKDRDLSDMSSANQVEPRALI ISPTRELTIQIFDEARKFSKDSVLKCHIIYGGTSTSHQMKQIFQGVDILVATPGRLLDLVGKGKITFDAIEFVVLDEADRMLDMGFLPDVEKVI IHNLLLKPREINDMGSLSTVEPRALILAPTRELAIOIHDECRKF SKDSVLKCCLIYGGTAVGHOLKOIFYGCDLLVATPGRLKDEVGRGKVVESAIEYLVLDEADRMI DMGE I GDVEMVI INTLLER--SVDLVVTSTYCEPQVVIVSPTRELTIQIWQQIVKFSLNSI LKTVVAYGGTSVMHQRGKLSAGCHILVATPGRLLDFVEKGRVKFSSVQFLVLDEADRMLDMGFLPSI EKMV INTLLER--SVDLVVTSTYCEPQVVIVSPTRELTIOIWOOIVKFSLNSILKTVVAYGGTSVMHORGKLSAGCHILVATPGRLLDFVEKGRVKESSVOFLVLDEADRMLDMGFLPSIEKMV INTLLER--SVDLVVTSTYCEPQVVIVSPTRELTIOIWQOIVKFSLNSI LKTVVAYGGTSVMHORGKLSAGCHILVATPGRLLDEVEKGRVKFSSVQFLVLDEADRMLDMGFLPSIEKMV

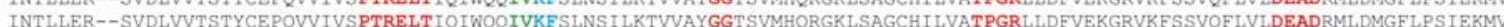
INTLLER--SVDLVTISTYCEPQVVIVSPTRELTIQIWQQIVKESLNSILKTVVAYGGTSVMHQRGKLSAGCHILVATPGRLLDFVERGRVKFSSVQFLVLDEADRMLDMGFLPSIEKMV
INTLLER--SVDLVVTSTYCEPQVVIVSPTRELTIQIWQQIVKFSLNSILKTVVAYGGTSVMHQRGKLSAGCHILVATPGRLLDFVEKGRVKFSSVQFLVLDEADRMLDMGFLPSIEKMV LSKLLEDP----HELELGRPQVVIVSPTRELAIQI FNEARKFAFESYLKIGIVYGGTSFRHQNECITRGCHVVIATPGRLLDFVDRTFITFEDTRFVVLDEADRMLDMGFSEDMRRIM

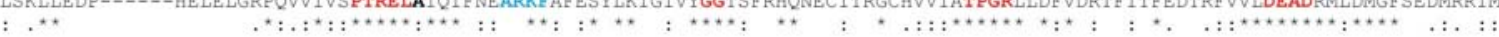

RHDTMKPPGERQTLMESATFPQEIQQLAAKFLNNYVFVTVGIVGSACTDIEQSFFEVKKSDKRTKLKELLNEEIEQNMLNGILVFVSEKKTADFIAALLSEDNFPTTSIHGDRLQREREE RHETMTPPGERQTLMFSATFPRDIQELAVKFLNNYI FVAVGIVGSACSDIEQSFLEVKKSDKRSKLKEILEEERNNDTLKGILVFVDQKRTADFIAAFLSDNNFPTTSI HGDRLOREREE

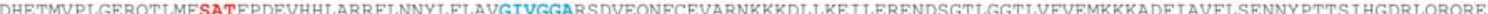
DHETMVPLGERQTLMESATFPDEVHHLARRFLNNYLFLAVGIVGGARSDVEQNFCEVARNKKKDLLKEILERENDSGTLGGTLVFVEMKKKADFIAVFLSENNYPTTS I HGDRLQRQREE DHETMVPLGEROTLMFSATFPDEVOHLARRFLNNYLFLAVGIVGGACSDVGRNFYEVARNKKKDLLKEILERENDSGTLGGTLVFVEMKKKADFIAVFLSENNYPTTSIHGDRLQROREE DHETMVPLGEROTLMFSATFPDEVOHLARRFLNNYLFLAVGIVGGACSDVGRNFYEVARNKKKDLLKEILERENDSGTLGGTLVFVEMKKKADFIAVFLSENNYPTTSIHGDRLOROREE DHETMVPLGERQTLMFSATFPDEVQHLARRFLNNYLLAVGIVGGACSDVEQNFYEVARNKKKDLLKEILERENDSGTLGGTLVFVEMKKKADFIAVFLSENNYPTTSIHGDRLQRQREE THVTMRP--EHQTLMF SATFPEEIQRMAGEFLKNYVSVAIGIVGGACSDVKQTI IYEVNKYAKRSKLIEILSEQADG-----TIVFVETKRGADFLASFLSEKEFPTTSI HGDRLQSQREQ

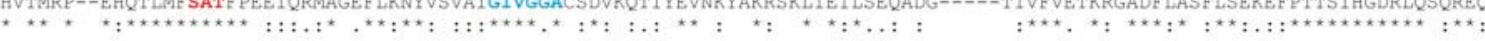

ALYDFKTGKMAILVATAVAARGLDIKNVRHVINYDLPKEIDEYIHRIGRTGRVGNKGKATSFFDPRYDEKLQGDLVRVLTQAGQEVPDWLASGAGESNYDG----PSDFGGQDIRNFDNAH ALNDFKSGRMCILVATAVAARGLDIKNVREVINEDLPKEIDEYIHRIGRTGRVGNKGKAVSFYDESIDNRIOPDLVKILEMANQPI PEWLASGAGYSNLG-----PSDFGAEDIRDFPNSS ALADFKSGRMSI LVATAVAARGLDI KNVSHVINYDLPKGIDEYVHRIGRTGRVGNRGRATSFFDPEEDAPLRGDLVRILKQANQSVPDWMMGGNANRNFMPGGGISKFGGEDVRESEAFA ALADFKSGRMSI LVATAVAARGLDI KNVSHVINYDLPKGIDEYVHRIGRTGRVGNRGRATSFFDPEEDAPLRGDLVRI LKQANQSVPDWMMGGNANRNFMPGGGISKFGGEDVRESEAFA ALADFKSGRMSILVATAVAARGLDIKNVSHVINYDIPKGIDEYVHRIGRTGRVGNRGRATSFFDPEEDAPLRGDLVRILKQANQSVPDWMMGGNANRNFMPGRGISKFGGEDVRESEAEA ALADFKSGRMSILVATAVAARGLDI KNVSHVINYDLPKGIDEYVHRIGRTGRVGNRGRATSFFDPEEDAPLRGDLVRILKQANQSVPDWMMGGNANRNFMPGRGISKFGGEDVRESEAFA ALADFKSGRMS ILVATAVAARGLDI KNVSHVINYDLPKGIDEYVHRIGRTGRVGNRGRATSFFDPEEDAPLRGDLVRILKQANQSVPDWMMGGNANRNFMPGRGISKFGGEDVRESEAFA ALRDFKNGSMKVLIATSVASRGLDIKNIKHVINYDMPSKIDDYVHRIGRTGCVGNNGRATSFFDPEKDRAIAADLVKILEGSGQTVPDELRTCG--AGGDGGYSNQNFGGVDVRGRGNYY

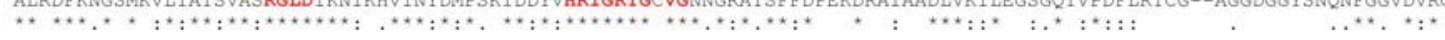

TSGGGTKPVEEDDEW----

GAQG-TLPVENDDAW---

EEYTEEAYSVAQEP--.-

EEYTEEAYSVAQEP---

EEYTEETYSVAOEP---

EEYTEETYSVAOEP---

GDATNVEEEEOWD

Figure S2 - ClustalW alignment of hymenopteran Vasa protein sequences, with Drosophila Vasa as outgroup. 